\title{
John LACHS, Stoic Pragmatism
}

Bloomington, Indiana University Press, 2012, 204 pages

\section{Matthew Caleb Flamm}

\section{(2) OpenEdition \\ 1 Journals}

Electronic version

URL: http://journals.openedition.org/ejpap/675

DOI: $10.4000 /$ ejpap.675

ISSN: 2036-4091

\section{Publisher}

Associazione Pragma

\section{Electronic reference}

Matthew Caleb Flamm, « John LACHS, Stoic Pragmatism», European Journal of Pragmatism and American Philosophy [Online], V-1 | 2013, Online since 16 July 2013, connection on 24 September 2020. URL : http://journals.openedition.org/ejpap/675 ; DOI : https://doi.org/10.4000/ejpap.675

This text was automatically generated on 24 September 2020

\section{(c) $\Theta \Theta \Theta$}

Author retains copyright and grants the European Journal of Pragmatism and American Philosophy right of first publication with the work simultaneously licensed under a Creative Commons AttributionNonCommercial-NoDerivatives 4.0 International License. 


\title{
John LACHS, Stoic Pragmatism
}

\author{
Bloomington, Indiana University Press, 2012, 204 pages
}

\author{
Matthew Caleb Flamm
}

\section{REFERENCES}

J. LACHS, Stoic Pragmatism, Bloomington, Indiana University Press, 2012, 204 pages.

1 The point of view endorsed in John Lachs's Stoic Pragmatism is easy to state, yet profound in its application. If pragmatists can be accused of sometimes underappreciating the irremediable, and stoics of sometimes being fatalist in a manner that shuts out real possibilities, the two orientations may need each other. His perspective combines a pragmatic commitment to amelioratory achievement and a stoic recognition of unbridgeable limits. As the book conveys, the marriage of stoicism and pragmatism is a reflection of Lachs's long-tread reflective journey, both in life and in print.

2 Lachs invokes stoic pragmatism in order to express the need for one's willingness to make the world better, yet to remain prepared for realism about lost possibilities, and to possibly surrender the fight when its continuance is futile. Not unlike individuals in a working marriage, each school affirms a key philosophic virtue the other seems to lack, so their union is one of potential mutual empowerment. Lachs suggests that, left alone, the two orientations risk a corresponding vice of excess, for: "stoics give up too soon and pragmatists make the mistake of never wanting to give up" (23).

3 Like most of Professor Lachs's works, this book is wonderfully free of technical jargon, and refreshingly strives to be actually philosophical, rather than accidentally so by way of obtuse theoretical frameworks. Lachs provides original diagnoses of key problems and offers sound proposals for ways through. The results are so obviously rewarding and apropos of genuinely philosophic reflection that it is unseemly to offer any formal critical reaction. And so, here I merely offer a reader's reaction. 
4 Perhaps, one might be tempted to argue, the marriage of pragmatism with stoicism risks anachronism. Given the lack of kindred scholarly efforts and the historical leap between eras in comparison there might be expected to be something obviously connecting the two, something more than the characteristics offered above. But Lachs's book is far more interesting than a sheer exercise in historical association, or theoretical reconciliation. Whether or not stoicism and pragmatism actually need one another is irrelevant: the point is, for Lachs, they do, and in his hands their marriage conduces to novel philosophic prescriptions. "Age clarifies." Lachs opens. "In the course of a life of reflection, one's attitude to the weightiest questions emerges only slowly" (1). And, it would seem, the time during which that attitude slowly emerges, the binding thread of various considerations can remain unacknowledged. "It was," he continues, "only recently that I managed to characterize my attitude to life as that of a stoic pragmatist. Once I did, it was easy to find traces of the position in earlier writings and in my decisions at crucial points in life" (1). So Stoic Pragmatism is in a significant sense a work of intellectual autobiography, though by no means of the sensational kind, spinning tales of personal struggle and triumph; instead, it is appropriately philosophic, a thoughtful exercise in self-evaluation that inventories the main trajectories of motivation behind the author's various preoccupations and applies them to various key questions.

5 The book is relatively short, divided into four chapters, with a very brief introduction and a philosophically confessional epilogue. The chapters thematically develop the book's overarching aim of deploying stoic and pragmatist strategies to resolve fundamental questions. The opening chapter, "What Can Philosophy Do to Make Life Better?" unequivocally establishes the target audience to include, if not privilege, the non-philosophical. While the treatment of major philosophers is hugely abbreviated and glossy, the presentation is appropriate for the purposes of the chapter and larger book. In just the first five pages Lachs covers the gambit of Thales, Plato, Aristotle, the British Empiricists, Continental Rationalists, and yes, Kant and Hegel! Certainly the discussion here is rapid-fire, roaming, conversational, and generally for the benefit of the unacquainted.

6 No doubt many of Lachs's characterizations of historical schools and figures are canned echoes of hundreds of classroom conversations he has developed for undergraduate students over the years: but they are the more charming and persuasive for that. Lachs has a true gift for bringing philosophy to life, for inviting the uninitiated into a table of conversation to which they perhaps never thought they were invited: "Plato's so-called theory of forms amounts to the idea that everything has a nature that it shares with other beings of the same kind" (4). Characterizations like these reflect the "vintage" charm of Lachs's invocation of philosophers and their ideas. The discussions are sincere and penetrating because they are inspired, rather than merely provoked, by major philosophic schools and figures. And besides, Lachs's worthy larger aim is to guide lay philosophic readers through some rather fat thickets of historical growth; ability to so guide requires knowledge of their depths. What counts in such an endeavor is not achievement or resolution of some new theoretical puzzle, but the opening of historical vistas capable of helping one appreciate the relevance of philosophy to life.

7 Accordingly, Lachs considers whether philosophy can any more produce public intellectuals. He identifies three ways that the discipline in its professional structure discourages "engagement with the broader public". Preferring argument over 
knowledge of current affairs and facts, incentivizing and rewarding technical obtuseness and obfuscation, and the misconceived categorization of philosophy alongside physics and anthropology, and/or science-directed inquiries that unfairly pit philosophy against more empirically-grounded rivals: all three of these, Lachs argues, account for the "retreat" of philosophy into the Ivory tower and its "abandonment of the traditional role as the critic of our beliefs and practices" (17). These criticisms of the professional obstacles to genuine philosophic reflection are not only fair, but much needed. John Lachs has achieved enough, to say nothing of occupied enough of a place and time in the profession, to have earned a stature to be able to say such things and expect someone to listen. This example of "power speaking truth to power" is rare, and, whether it bears fruit in the present case, it well may have done so in the past. For some amount of years Lachs has not hesitated holding views to which some of his closest colleagues object, and, as he confesses in the book's epilogue, has raised objections to powerful administrators. Such sincere fidelity to conscience and truth is, to say the least, admirable and rare.

Lachs's purpose of achieving larger connections is one that has been fairly consistent throughout his philosophic career, at least since the mid-90's, addressing himself to the worthy question: why philosophy? Why does it matter? In Stoic Pragmatism Lachs appears to be taking a longer inventory of things, squaring his early-career defenses of epiphenomenalism and discussions of human nature and mediation (see especially Intermediate Man [1981] and Mind and Philosophers [1987]) with his current point of view. Not dissimilar from the inventory taken by Lachs's philosophic model, George Santayana in the "Apologia" he published in the Library of Living Philosophers edition devoted to his thought, Lachs sees tremendous continuity between his current and earlier perspectives: "Once I [settled on the 'stoic-pragmatist' characterization of my attitude] it was easy to find traces of the position in earlier writings and in my decisions at crucial points in life" (1).

Chapter three of the book illustrates Lachs's original ability to think through fundamental issues using the resources of American philosophy as his guide. He critically considers forms of "human blindness" as provoked by claims in William James's famous essay of the same title, and, using James's famous discussion of "moral holidays" in his Pragmatism lectures, sets up an interesting framework for considering the sharp contrast between James and his absolutist nemesis Josiah Royce. The implied critical wedge of Lachs's deft analysis is the naturalist perspective of his philosophic forebear, Santayana. Lachs does a great job of exposing the too-overlooked, but nevertheless shared moralism of James and Royce. He pulls out the senses in which James's "Moral Philosopher and the Moral Life" reveals him to possess the "same moral fervor" as his erstwhile adversary Royce. Lachs's treatment of the interesting relation between James and Royce is clearly the result of a close study of Santayana, as is inferred from the fact that he is so easily able to call their moralistic bluff.

One point of criticism I must identify, Lachs's open-palmed stance and ground-level, common-sense narrative at times loses some of its power when certain unnecessary moral assessments seep into considerations. These tend to bubble up, revealingly, in his occasional indulgences in sharp personal criticism or reprimand. On multiple occasions Lachs chides logic-chopping philosophers of language for their phoniness, and calls out merely "professional philosophers" for setting up obstacles to genuine philosophic engagement. These laments are mostly well-taken, and well-placed, for example in the 
first-chapter section "Can Philosophy Produce Public Intellectuals Today?" where, as indicated, he justifiably calls attention to the various senses in which the "profession" has set up obstacles to genuine philosophic engagement.

11 But these observations are sometimes combined with unfortunate remarks that unnecessarily reveal Lachs's personal aversions, as when he emphasizes the unique duty philosophers have of practicing what they preach: “...inner divisions are relatively harmless in the case of chemists, whose professional views may have little bearing on their lives. But lawyers who violate the laws, atheist priests, bankrupt financial advisors, and obese physicians, along with irrational philosophers, rightly arouse suspicion" (18-19).

One cannot help wincing a bit at such characterizations. The point about disingenuous philosophers is worth making, but one wonders whether it adds anything to the point to offer directly unflattering descriptions-among others he makes, Lachs mentions William Bennett's "excessive bouts of gambling" and the "spewing" of "mindless Leninism" by Hilary Putnam. Perhaps more hazardous: why say anything of professions or disciplines that allegedly require more or less coordination of "inner and outer" convictions and commitments? It all seems a rather slippery slope to travel for a narrative that is so otherwise balanced and seeking of reconciliation and relief from impenetrable puzzles. It is not clear but, whether or not Lachs is suggesting that obese physicians have anything in common with rapping philosophers (Cornel West is suggestively included in the discussion), their very association seems curious at best. I simply suggest that this occasional injection of personal bias undermines the otherwise refreshingly open-minded narrative of which Lachs is a veritable master.

13 I must leave to other more qualified commentators the task of fully evaluating the various interesting remarks Lachs makes about the challenge pragmatists face regarding questions of ultimate limit, including especially, the problem of death. It is enough here to saythat the challenge has been raised, and that Lachs takes seriously the idea that it may be a problem for the pragmatist orientation specifically: "It is understandable that critics should hold pragmatism accountable for what it says about death" (53). Perpetual improvement of life ("amelioration") being the hallmark of pragmatism, it makes sense that final ends fail to find a comfortable category in the pragmatist framework. That said, as Lachs takes pains to show, pragmatists do attempt an answer: "The question of what pragmatists would have us do in relation to death has a simple answer: fend it off one day at a time" (60). "Work on death" may not sound like an immediately helpful strategy to those in perilous distress over it, but it does seem a reasonable way of expressing what is likely the only recourse pragmatists have if, as Lachs holds, its sole commitment is to the "improvement of life here and now".

This book should be front-listed in general undergraduate courses on philosophy, and pushed and marketed in bookselling contexts aimed at audiences of broad intellectual interest. The presentation is intellectually conversational, and helpfully devoid of technicaltheoretical complications. Professor Lachs proves himself here, as in previous publications, to be an ideal purveyor of philosophic ideas to an inquisitive public. 


\section{AUTHORS}

\section{MATTHEW CALEB FLAMM}

Rochford University

mflamm[at]rockford.edu 